\title{
Experiences of Intensive English Learners: Motivations, Imagined Communities, and Identities
}

\author{
Juyeon Lee ${ }^{1}$ \\ ${ }^{1}$ Graduate School of Interpretation and Translation, Hankuk University of Foreign Studies, Seoul, Korea \\ Correspondence: Juyeon Lee, Graduate School of Interpretation and Translation, Hankuk University of Foreign \\ Studies, 107, Imun-Ro, Dongdaemun-Gu, Seoul, Korea. Tel: 82-10-9932-6769. E-mail: juliajustin@gmail.com
}

\author{
Received: August 13, 2014 Accepted: September 15, 2014 Online Published: October 23, 2014 \\ doi:10.5539/elt.v7n11p28 URL: http://dx.doi.org/10.5539/elt.v7n11p28
}

\begin{abstract}
Based on a widely held belief that immersion provides the best language learning opportunities, a large number of Asian students go to English-speaking countries to improve their English language skills. These strongly motivated learners arrive in a new country with a bag of expectations, learner beliefs, and imaginations about the new community they are about to enter. However, learners are often faced with a set of challenges with respect to language learning opportunities and identity negotiations in the new community. Against this background, the present study examined three cases of Korean learners enrolled in an intensive English program (IEP) in the U.S. The aim of the study was to understand distinct struggles experienced by this learner population. The study found that the participants had certain motivations and imaginations about the new communities, but they experienced numerous challenges and struggles particularly with regard to opportunities for authentic communications in English and identity conflicts. The paper discusses pedagogical implications for an effective IEP curriculum to allow students more opportunities for legitimate periphery participation in the target language communities of practice.
\end{abstract}

Keywords: intensive English programs (IEP), immersion, adult ESL learners, imagined communities, identities

\section{Introduction}

As English is becoming increasingly recognized as the global language of commerce and technology, English proficiency is considered an important skill in the job market in many Asian countries (Kim \& Yang, 2010; Weger, 2013). In recognition of the importance of English in the global context, a growing number of students from Asia come to the U.S. for intensive English as a second language (ESL) study. Many of them are enrolled in intensive English programs (IEP), which refer to "a context in which learners is explicitly studying English alongside learners from diverse first language (L1) backgrounds while in an English-dominant community" (Weger, 2013, p. 89). These programs are predominantly affiliated with universities in the U.S.

While these learners are often identified in the Second Language Acquisition (SLA) literature as ESL learners, referring to IEP learners as ESL learners may run the risk of masking important differences between temporary sojourners, matriculated international students, and permanent immigrant populations. These groups may exhibit substantial differences with respect to a wide range of factors including language learning histories, motivations, beliefs, identities, and social contexts. In particular, IEP learners from Asia invest time and money to study in English-speaking countries. Their main purpose of the study abroad is to improve English, which makes them distinguished from immigrants who have moved to a new country to stay permanently and matriculated international students who are pursuing academic degrees. As such, motivations, expectations, identity negotiations, and language learning experiences of this population are distinct from other ESL learner populations (e.g., Kim \& Yang, 2010; Weger, 2013).

There has been extensive research on identity and English language learning experiences of immigrants in the U.S. (Pavlenko \& Lantolf, 2000; Schecter \& Bayley, 1997; Watkins-Goffman, 2001, among others). Also, there is a sizable body of research on the study abroad experiences of American students (e.g., Freed, 1995; Kinginger, 2004; Talburt \& Steward, 1999; Wilkinson, 1998). As pointed out by Weger (2013), IEP learners have been subjects of many SLA studies largely due to the fact that such learners are easily accessed for research by university-based researchers. Yet, there seems to be lack of research that specifically investigated their L2 motivations, L2 learning experiences, and identity-related struggles. In this context, the present study explored 
the experiences of three IEP learners from Korea with a particular focus on their motivations, learner beliefs, and changes in identities. Specifically, the following research questions were addressed: (1) What were the learners' motivations to study English abroad? (2) What kinds of struggles did the learners experience in their attempts to immerse in the target language community and position themselves as English speakers? (3) What approaches were taken in response to struggles in language learning in an IEP context? It was hypothesized that various motivational and contextual factors shape and reshape the participants' language learning experiences and struggles related to identity negotiations have an impact on their experiences in the target community. Findings of this study have pedagogical implication that may contribute to improved intensive English programs.

\section{Background of the Study}

\subsection{Sociocultural Theory and Second Language Acquisition}

The present study approaches second language acquisition from a Vygotskian perspective, which frames language learning in social terms (Lantolf, 2000; Swain \& Lapkin, 1998). Vygotsky argued that humans rely on physical tools as well as symbolic tools to mediate and regulate relationships with themselves and others. Language is one of the most powerful and important symbolic tools that mediate these relationships (Lantolf, 2000). Also referred to as the sociocultural theory (SCT) of second language learning, this approach puts emphasis on the role of language as a cognitive mediator and its attention to the social and cultural aspects of learning. In this line of research, it can be argued that individual learners' experiences need to be examined in relation to their unique social and cultural contexts rather than treating learners as a homogeneous group of people who receive and acquire L2 input in a uniform manner.

In criticizing the cognitive tradition in SLA which tends to focus on the cognitive learning process of individual learners without taking into consideration of the surrounding social contexts, Johnson (2004) proposes a new model for SLA theory and research based on sociocultural theory. She argues that the origin of second language competence lies in social reality and in language use. The language use takes place in a "real and discernible social context" (p. 172). Therefore, the local and contextual nature of language ability and language learning need to be understood. As such, the present study examined the contextual factors that influence IEP learners' experiences.

Within the framework of sociocultural theory, learning is explained using the participation metaphor (PM) that can compliment the acquisition metaphor (AM). Sfard (1998) regarded PM as learning through the process of gaining full membership in a community. While AM prioritizes the acquisition of certain knowledge on the part of the learners, PM focuses on interactions between the learner and the learning contexts. Pavlenko and Lantolf (2000) explain that PM allows researchers to "shift the focus of investigation from language structure to language use in context, and to the issues of affiliation and belonging" (p. 156). Following this view, the present study regards second language learning as a process of gaining access to and membership in the target language community.

\subsection{Second Language Learners' Identity and Investment in Imagined Communities}

Within the larger framework of SCT, several key notions have been applied in the present study to discuss language learning experiences of three IEP learners from Korea. First of all, the relationship between identities and language learning is examined. In recognition that the social world and language learners cannot be understood separately, Norton (2000) claims that second language theorists need to study the relationship between learners' identities and language learning experiences. She uses the term identity to refer to "how a person understands his or her relationship to the world, how that relationship is constructed across time and space, and how the person develops a conception of identity that is understood with reference to the learner, and frequently inequitable social structures which are reproduced in day-to-day social interaction" (p. 5). For instance, an English language learner may wish to be understood and recognized as a legitimate speaker of English, while native speakers interacting with him may not accept such a bid but rather be inclined towards defining him as a non-native speaker. The inequitable process of developing and negotiating identity is evident in the experiences of many ESL learners, which are discussed in the three case studies in the present study.

The inequitable process of negotiating identities may be a struggle for learners. Thus, Norton (2000) calls identity "a site of struggle" (p. 17). While a person may be positioned in a particular way in a given discourse, the person might resist the subject position, thus creating conflicts. In particular, second language learners are often given subject positions that they do not want to assume, and they need to struggle to claim certain positions they wish to represent themselves in. Specifically, Hawkins (2004) argues that participants in situated social interactions make bids for certain identities. The bidding process involves approximation of available resources. One needs to know which identity is appropriate for what purpose and when, in order to be recognized as a 
legitimate participant of a society. In other words, "the interaction in terms of the way language is used and participation is structured invites participants to take on certain sorts of identities" (p. 18). However, second language learners often lack such ability to use their "language tool kit" (p. 17) in a socially appropriate way, which results in the rejection of their claims for certain identities in the target speech community. In this regard, the present study explored how the learners made bids for certain identities, how they dealt with rejections, and how these experiences resulted in certain decisions.

Another notion closely related to identity and language learning is the concept of investment in imagined communities (Pierce, 1995), which is useful in understanding L2 learners' motivations and participation in language learning. Kanno and Norton (2003) define imagined communities as "groups of people, not immediately tangible or accessible, with whom we connect through the power of our imaginations" (p. 241). As the authors explain, language learners are not only engaged in immediately accessible communities, which are communities of practice, but also affiliated with imagined communities that affect their learning. For instance, in a qualitative case study, Kim (2013) shows how a Korean graduate student in the U.S. has made investments in academic English in hopes of gaining membership to an imagined Korean elitist community that may afford high social status and financial success. Similarly, in the present study, the notion of investment in communities of practice as well as imagined communities is utilized to account for factors that trigger certain decisions that L2 learners made in an IEP context.

\subsection{Previous Research on L2 Learners' Motivations, Identities, and Language Learning Experiences}

A handful of studies concerning IEP learner populations have informed the present study that attempted to understand IEP learners from Korea with respect to their identities, language learning motivations, and experiences. For instance, Weger (2013) administered a questionnaire to 131 IEP learners to investigate their language attitudes, learning orientations, and learning confidence. In this quantitative study, $70.3 \%$ of the participants were Asian, of which $60 \%$ were Korean. The results show that the Value of English Learning factor received the highest factor score, which may suggest learners' recognition of the linguistic capital they hope to obtain from learning English. In contrast, the Attitudes toward English Language Community factor and the Learning Self-Confidence factor received the lowest scores. These findings seem to indicate that IEP learners are not mainly motivated by positive attitudes towards the target language communities in their language learning. They also seem to lack self confidence in language learning even though they study English 20 hours a week in a university-based IEP.

Meanwhile, Kim and Yang (2010) conducted a qualitative study to investigate the role of L2 learner beliefs in IEP contexts. Data collected from two Korean college students show that changes in L2 learning beliefs have influenced the degree of participation in English language learning. The authors conclude that the crucial factor for successful language learning in an IEP setting may be the learners' recognition of and appreciation for participation in the communities of practice in the target language.

As for the literature on L2 learning in study-abroad contexts, the majority of the studies have been concerned with American college students who went abroad for a short period of time as part of foreign language programs. For instance, Allen (2010) investigated motivations and learner beliefs of two American students who went abroad to study French and found that their different motives and goals led to differences in L2 learning experiences and language learning strategies. Also, Talburt and Stewart (1999) carried out an ethnographic study to explore cultural learning experiences of study-abroad students in Spain. They argue that gender and race identity play a critical role in shaping cultural learning for study-abroad students in and out of the classroom. In another study, Kinginger (2004) traced for four years a female French learner to understand how her identity was reshaped through her language learning experiences and in particular her study-abroad experiences.

As briefly reviewed in the above, studies have been carried out on immigrant language learners who intend to live in the U.S. permanently and American students who participate in short-term study-abroad programs. However, there is relative lack of research on Asian students who come to the U.S. to learn English in intensive ESL programs. While a large number of SLA studies have recruited IEP students as participants primarily for the reasons of accessibility (Weger, 2013), only a handful of studies have attempted to document their language learning experiences and struggles from the learners' perspectives using a qualitative research method. In arguing for the value of first-person narratives in the field of SLA, Pavlenko and Lantolf (2000) criticize that one of the reasons why this type of narrative has been marginalized is that they are "the experience of becoming and being bilingual and have been produced by people who themselves are frequently marginalized" (p. 157). Recognizing the under-representation of the voices of IEP learners, the present study attempts to explore and document the motivations, investments, and identity struggles of three IEP students from Korea. The findings of 
the study are expected to expand our understanding on this learner population and contribute to improving more than 350 accredited intensive English programs in the U.S. (American Association of Intensive English Programs, 2014) as well as similar programs in other English-speaking countries.

\section{The Study}

\subsection{The Participants}

For the purpose of exploring IEP learners' language learning experiences with respect to motivations and identities, three Korean learners of English were recruited based on several criteria. First of all, they have completed at least one semester of 14 weeks at an intensive English program so that they could describe their experiences of taking English classes and trying to get accustomed to the new community. Secondly, they were all planning to return to their home country within a year from the time of data collection, which makes this cohort distinct from other ESL learner populations that include matriculated international students and permanent immigrants. Thirdly, they received a minimum of six years of English as a foreign language (EFL) education in Korea prior to the study-abroad experience. Finally, their main goal of coming to the U.S. was to improve English, which is indicative of their strong desire and motivation for language learning. The background information of the participations is summarized in Table 1.

Table 1. Characteristics of the participants

\begin{tabular}{lllll}
\hline Name & Gender & Age & Sessions taken & Length of stay in the U.S. \\
\hline Mina & Female & 22 & 2 & 6 months \\
Jisun & Female & 24 & 2 & 7 months \\
Seungho & Male & 25 & 3 & 9 months \\
\hline
\end{tabular}

With respect to the setting, the ESL program attended by the participants (the Program) is affiliated with a four-year state university in a Northestern state in the U.S. The intensive ESL courses are organized by four disciplines, namely grammatical structure, phonology, reading and writing, and discussion. Two seven-week sessions are provided in the fall semester, two in the spring semester, and one in the summer. The Program serve approximately 130 ESL learners from countries around the world, the majority of whom are from Asia. At the time of the data collection, nearly $80 \%$ of the total students enrolled in the Program were Korean.

\subsection{Data Collection and Analysis}

For the purpose of exploring and documenting motivations, beliefs, identity struggles, and related learning experiences in a detailed manner, grounded theory methodology was employed, which is used to study multiple individuals who have participated in a process about a central phenomenon (Creswell, 1998). In the present study, the phenomenon under investigation is studying English in an intensive English program. In this qualitative research tradition, the typical data collection method is interviews. In the study, two interviews were conducted with each of the three participants. The first interview focused on motivations behind their decision to come to the U.S. and the overall experiences of taking ESL classes and living in the new country. The second interview was concerned with how their experiences have influenced their perspectives on selves. Each interview lasted for approximately an hour at a time. The interviews were conducted in Korean, the L1 of the participants, in order to allow the learners to express their thoughts and feelings more accurately.

The in-depth interviews were in a semi-structured format based on the general interview guide to describe the meaning of the study abroad experiences of the participants. The researcher respected how the participants framed their responses (Marshall \& Rossman, 1999) to prevent the researcher's views from influencing the participants' responses. A digital audio recorder was used to record the interviews. Audio files were dated and labled separately for each participant. Throughout the paper, pseudonyms are used to maintain confidentiality of the participants.

To prepare for an in-depth data analysis, the entire interviews were first transcribed and then translated to English by the researcher who holds an M.A. in translation and interpretation. The data were analyzed based on the grounded theory methodology (Strauss \& Corbin, 1998), consisting of three coding phases. First, the interview transcripts were examined for all the salient categories of information, which involves coding of related topics. Then, the researcher re-read the data iteratively for the purpose of selective coding. In the final phase, the relations among the thematic categories were explored and elaborated. Through this rigorous process, 
relevant thematic categories and their relations emerged from the data that allowed the researcher to pattern and demonstrate distinct experiences narrated by the three participants during the interviews. The results of the qualitatitve analyses are presented and discussed in the next section.

\section{Results}

\subsection{Imagination: Motivations and Expectations}

\subsubsection{Mina's Story}

Mina is a 22-year-old senior college student majoring in political science at a prestigious university in Korea. Born into a middle-class family, she had never lived away from her family before she came to the U.S. to study English. Several factors motivated her to study abroad in the U.S. First of all, her private English tutor for three years in high school was a major influence. The tutor had studied English in the U.S. when she was in college. During tutoring sessions with Mina, she often shared anecdotes of how wonderful her experience was in America. To Mina, everything about America sounded exotic, beautiful, and ideal. In the interview, Mina admitted that she began to idealize Americans and their ways of living as a teenage girl.

Another source of influence was a group of friends who had gone abroad to study English and came back with positive experiences. One of her friends went to New Zealand for six months, and her English proficiency improved dramatically as she dated a New Zealander. Another friend of hers said that her perspectives had broadened significantly after spending a year in the U.S. Social pressure that everyone is going abroad to gain experience and improve English skills also influenced her decision to study English abroad. Kim (2008) reported that a widespread belief among Koreans is to equate high English proficiency with better job opportunities. Mina shared this belief in saying that employers prefer to hire those who have study-abroad experiences and that English skills are essential in the job market regardless of industry sectors.

With respect to imagined communities, Mina imagined herself to be a member of an international organization. As a political science major, she had a dream of working at an international agency such as the UN. Mina figured that a high level of English proficiency and a global perspective would bring her one step closer to realizing her career aspiration. In addition, her imagination of American society was partly based on the media, which is often the case as suggested by Kanno and Norton (2003). She had been impressed with fashionable people in New York City as TV shows and movies often pictured Americans that always look happy and free.

\section{Excerpt 1.}

Mina: In American movies, I see that people are very energetic and the weather is always nice. People are smiling and saying hi to one another on the streets. They hang out at coffee shops and have a good time. That kind of atmosphere, I've seen a lot in movies. I think I was influenced by those images. You know, in Friends, the characters always have a good time. I thought it would be really fun and exciting to live in America.

As seen in Excerpt 1, she imagined the target langauge community to be filled with friendly, happy people. She was excited for the prospect of being immersed in the community. Similar to the expectations held by the Korean participants in Kim and Yang's (2010) study prior to their study-abroad trips, Mina hoped to have many opportunities to interact with native speakers and make friends with them. She imagined herself talking with people on the streets, on the train and in restaurants. She expected that her English proficiency would improve significantly in a short period of time through these authentic interactions. In short, she became motivated by what she heard from her friends and her Englsh tutor. Her imagined communities were mediated by stories told by her friends and tutor, widespread beliefs about study-abroad in Korean society, as well as television and the media.

\subsubsection{Jisun's Story}

Jisun graduated from college with a major in piano performance just before the study abroad. At that time, she was not sure what she really wanted to do with her life. Her wish to spend some quiet time to reflect on her life and plan for the future coincided with her aunt's invitation for a trip to the U.S. Jisun's aunt is married to an American and has lived in the U.S. for almost 20 years. They have one son. Jisun visited them for a month when she was in middle school. Thanks to this trip, she became fond of America. In the interview, she recalled that everything seemed so big to her, the air was clean, and people looked so relaxed and happy. Jisun imagined an ideal community in a similar manner with Mina.

Furthermore, when Jisun was young, her aunt's family visited Korea a couple of times. When she met them, Jisun was eager to communicate with her uncle, using her limited English. She recalled that she really enjoyed showing them around in Korea. Thus, when her aunt asked her to visit her family in the U.S., Jisun was excited 
about the prospect of living in a different country. In short, her decision to study English in the U.S. was mainly motivated by her aunt's invitation, and her imagination about the target language community was primarily mediated by her previous interactions with the aunt's family.

\subsubsection{Seungho's Story}

At the time of the interview, Seungho was taking a year off from college education. After completing the freshman year in college, he went to serve in the military, which is mandatory in Korea. After two years of military service, he returned to college and studied civil engineering and worked part-time at an architect office for two years. Now that one more year was left before graduation, Seungho decided to take some time off from school.

English was a major concern for him. When he tried to convince his parents to send him to the U.S., he emphasized the importance of the English language in today's global world. He argued that English would be very useful if he wanted to take on graduate study, start his own architecture design business, or carry out joint projects with architects from other countries. It seems that Seungho shared a similar belief with Mina that higher language proficiency would contribute to better job prospects.

Another source of motivation was the presence of relatives in the U.S. His aunt's family was in the U.S. with two children, who were native speakers of English. One of them was a college student. Seungho thought his cousins would help him make the best of his time in the new country even though he did not plan to depend on his relatives financially or with respect to living arrangements.

Seungho had three goals in mind when he prepared to come to the U.S. First, he wanted to develop the ability to carry on conversations with people in English. Second, he hoped to improve his English writing skills. He believed that solid academic writing was what he needed most. Finally, he wanted to learn about different perspectives and values of Americans, and college students in particular. From the first interview, it became clear that Seungho was a motivated learner with specific goals to achieve. He imagined that the immersive environment together with the IEP curriculum would allow him to accomplish what he envisioned.

\subsubsection{Summary}

There were similarities among the three participants with regards to their motivations and imaginations about the target language communities. Their key motivation was to improve English language competence by studying in an English-speaking community. They believed that living in the target speech community would afford them with plenty of opportunities to interact with people in English, which would result in higher English proficiency. They imagined members of the target community to be welcoming, helpful, and friendly towards them. These imaginations were influenced by anecdotes from acquaintances, widespread beliefs in Korean society concerning effectiveness of study-abroad, and the portrayal of America in the media. They expected to gain access and membership to the communities of practice with ease.

However, there were differences among the participants with regard to family ties. Mina had no relatives, family, or friends in the vincinity. In other words, she had to deal with everything on her own. On the other hand, Jisun had been maintaining a good relationship with her aunt's family and hoped to spend time with them. Likewise, Seungho had his aunt's family in the area and his cousin was attending the university where the IEP was located. These family ties would offer emotional and identity support to the two learners while Mina practically had nobody to depend on.

Motivations, expectations, beliefs, and imaginations about the target language communities mediate language learning experiences and identity negotiations of L2 learners. In particular, learners may experience frustration when their expectations are not met. The next section discusses how the idealized communities imagined by the participants and their high expectations were challenged in reality.

\subsection{Reality: Struggles}

\subsubsection{Struggles to Find Opportunities to Interact with Native English Speakers}

The biggest struggle that the participants had to deal with was to find opportunities to interact with native English speakers. As stated earlier, all of them expected they would have plenty of chances to converse with friendly Americans who would be willing with talk with them. However, the reality was different. Kim and Yang (2010) reported that one of their Korean IEP students, Jana, had frustrating moments when her expectation of being immersed in L2 input-rich contexts were not matched with opportunities to speak with native English speakers. Similarly, the three participants expressed strong disappointment and frustration regarding the lack of opportunities to have authentic communication with native speakers. 
The participants pointed out that the Program was not helpful in providing them with such opportunities. First of all, there were so many Korean learners at the Program. As mentioned in Section 3, nearly $80 \%$ of the students at the Program were Koreans. Mina said, "This place is like a miniature Korea." She added that the Program felt very much like private English language institutes in Korea. Thus, her expectation of L2 input-rich environment was not met. The immediate environment of the participants consisted of students from Korea as well as learners from other countries who are not native English speakers.

Seungho also mentioned that "The Program students are guests to the university. That's what it says on my student ID card." Even though the Program classes are held on the university campus, students are given the status of a guest and thus not eligible to many benefits and privileges available to the university students. Also, life at the Program was isolated from the life of other university students, as expressed by the participants in Excerpt 2.

Excerpt 2.

Mina: It's hard to make friends with university students. There is no such opportunity.

Jisun: Our classes are held in the morning, but it seems that university students are active later in the afternoon. So I think our daily schedule is quite the opposite of theirs.

Seungho: I heard that the Program is completely independent of the university. It is just located in the campus but a separate institute.

Unlike other community college ESL programs, students at the Program are not allowed to take regular university courses for credit. There is no home-stay program or language exchange program with the university to provide learners with opportunities to interact with university students. Furthermore, a section of the dormitory complex available to the IEP students is separated from other sections occupied by university students. In a given day, the participants were surrounded by their peers from Korea and other non-native English language learners even though they were physically situated on the university campus.

The situation outside the Program was not much different. On the streets and in the neighborhoods, the participants saw local Americans, but they were not willing to talk with them. Kim and Yang (2010) reported that their participants imagined "an ideal study abroad context where all local English speakers around them would be willing to support their L2 development" (p. 91). Likewise, the participants in the present study imainged the friendly and supportive communities where they would be able to interact with local members. However, the reality was the opposite of their imagination as expressed by Mina in Excerpt 3.

Excerpt 3.

Mina: For example, I see Americans on campus or at the supermarket. But, there is nothing much I can do with them. I cannot just walk up to them, say hello and talk with them or make friends with them. So I would just see them and walk by them, and that's pretty much it.

Recognizing limited opportunities to meet native speakers in and out of the Program, the participants actively searched for such opportunities in the local communities. However, they often experienced struggles in attempts to present themselves as legitimate members of the communities.

\subsubsection{Struggles to Claim Identities as Legitimate English Speakers}

The analyses of the interview transcripts revealved that the participants experienced inequitable processes of negotiating identities. They wanted to be understood and recognized as legitimate speakers of English, but native speakers interacting with them often did not accept such bids and defined them as foreigners or non-native speakers. In these situations, the participants tended to give up on further negotiations of identities and place blame on their lack of native-like language proficiency.

For instance, in an attempt to increase exposure to English language input and make friends with native speakers, Mina moved into a room in an apartment she shared with three roommates. However, the roommates often did not recognize her status as a legimate roommate. She commented on how she felt when her roommates did not inform her of some changes in the apartment rent contract.

\section{Excerpt 4.}

Mina: In the apartment, things are always handled like that without me, you know, because I don't speak good English. When you are treated unfairly, you need to confront them, right? But I can't. I have things that I want to say but I just cannot.

Faced with unfair treatment, Mina wanted to confront the roommates but her lack of confidence in English 
competence kept her from doing so. Similarly, Seungho moved out of the dormitory to an apartment shared with three American students. Here, he had similar experiences as Mina. He made attempts to get along with the roommates and become friends with them, but it was challeging.

Excerpt 5.

Seungho: When I first moved in, I was mostly ignored and excluded maybe due to my limited English. I was not very happy about it, and I was trying to figure out why. It could have been my poor English, or it could be something else. Maybe it could be that they did not accept me because I was different. I am Asian, you know.

In Excerpt 5, Seungho perceived that the only identity that his roommates imposed on him was an Asian who was not fluent in English, and he was not happy about it. Seungho also described similar experiences at fast food restaurants and how employees who received orders were not patient with him and did not recognize him as a legitimate speaker of English in the local communities. He had imagined that he would be afforded ample opportunities to interact with members of the target language communities in a variety of settings, but he did not know that such opportunities would be accompanied with negotiations of identities.

In addition, the participants felt that their identity as students in the Program was not respected much. In the interview, Jisun pointed out that some teachers at the Program did not delivery quality instruction but did not seem to care much because they believed that students would not be able to complain effectively in English.

Excerpt 6.

Jisun: When teachers don't prepare for their classes, students all know that. We may not show it because we are not really confident in expressing our concerns in English. We cannot explain in detail why some teachers are not very good. Even if we complain, the Program administrators do not seem to listen to us because nothing really changes. But among us, we know who are good teachers and we care about teachers' quality.

The above excerpt suggests that many students at the Program felt that their right to quality of education was not respected and their learning needs were not properly addressed. Learners struggled outside the classroom, and they also felt disrespected in the classroom as well.

\subsection{Strategies to Deal with Challenges}

As described in the above sections, the participants came to the U.S. with a set of positive expectations about the study-abroad experience and imaginations about target language communities. In the new country, the learners experienced struggles to have authentic interactions with local community members and struggles to negotiate identities. In dealing with these challenges, the participants adopted rather different strategies, which seem to have been influenced by their motivations, learner beliefs, and available resources.

Initially, Mina did not want to spend time with other Koreans at the Program. She wanted to expose herself to an immersive environment as much as possible. That was a primary reason she decided to live in an off-campus apartment with American roommates instead of living at the dorm with other classmates. However, unlike her expectations, she felt unaccepted and unrecognized by her roommates as illustrated in the previous section. Since she felt lonely and isolated, she realized that she needed social networks with other Koreans who could provide her with emotional support. She did not identify herself as a speaker of English or even a user of English. She did not develop a sense of belonging to the new community. Mina used more Korean than English in her daily life. She commented that she felt defined as a "foreigner" by other Americans. With no relatives or family members in the neighborhood, Mina began to develop a strong association with her Korean church. This church was attended by a small number of Korean families who took care of her like their own family. She sought after family-like support and emotional security through the church network. She confessed that her English had not improved as much as she had hoped. However, Mina had to depend on her Korean friends at the Program and the Korean church to sustain her self-confidence and survive in the new country.

On the other hand, Jisun's approach can be summarized as a "no Korean friend" strategy. She said she did not feel embarrased or frustrated by the fact that her English was not good enough because she defined her identity as a "language learner". She concluded that spending too much time with other Koreans at the Program would not help her reach the goal. She also tried to create opportunities to be closer to native speakers. For instance, she went to the gym on campus not only to exercise but also to be closer to university students. She would overhear their conversations and observe how other Americans would socialize and communicate in English. She would see people on the streets talking with their friends. However, she felt disconnected and distant from them. She did not feel like a member of the local communities but a mere observer and an outsider.

Since Jisun was not able to make friends with local Americans as imagined, she turned to her dorm friends from 
other countries and her aunt's family for social support and a sense of belonging. Her classmates who live in the dormitory provided opportunities for her to use English in authentic communications and understand others' cultures and perspectives.

\section{Excerpt 7.}

Jisun: I like living in the dorm. It's a lot of fun, and I think we have created our own dorm community. We often call ourselves a dorm family. We are very close to one another and because we are all in similar situations, we can really understand and support each other.

She was also fortunate to receive support from her aunt's family. Jisun visted her relatives on weekends where she had an opportunity to talk with her uncle who is a native speaker of English. He sometimes helped her with writing, vocabulary, and pronunciations. Her aunt would cook Korean food for her, which helped ease her homesickness. Furthermore, her cousin and his girlfriend who were attending the university helped her meet native speakers. They would take her to some social events where she was able to gain cultural and language experiences.

Seungho's approach presents yet another picture. Recognizing the situation that there are so many Korean students at the Program and that it is very hard to interact with native speakers, he made a conscious decision to try to balance his socializing with Koreans versus classmates from other countries. He felt that he would be socially isolated if he had stayed detached from other Koreans in the Program, but his English would not improve as much if he had been with Koreans only. For this reason, he adopted a strategy of maintaining a balance between Korean friends and IEP learners from other countries. He commented that his approach had been successful because he was able to make a lot of foreign friends and maintained good relationships with other Koreans at the same time. Seungho said he did not regret taking the approach of balancing his socializing with Koreans and learners from other countries at the Program. He also received support from his Korean-American cousin who was attending the university. However, he pointed out that he did not really have opportunities to gain membership to a larger community. His communities were limited to students at the Program and some friends of his cousin's.

\subsection{Pedagogical Implications}

The findings of the study have pedagogical implications that can contribute to improving intensive English programs in English-speaking countries. First of all, the results show that IEP learners tend to feel disappointed and discouraged when the reality is different what they imagined, which involves abundant opportunities to interact with native speakers. For this, the programs can make efforts to create such opportunities for their students. For instance, IEPs may collaborate with university foreign language programs to allow students to be paired up with university students for language and cultural exchange. These pairings can be beneficial to both groups of learners.

Volunteer programs may also provide opportunities for IEP learners to contribute to the local communities and interact with members of various groups. Indeed, Kim and Yang (2010) reported that one of the participants volunteered at a local nursing home where her efforts of contributing to the community were appreciated by the local members and she achieved a strong sense of membiership in the local community. Likewise, IEPs may form partnerships with local NGOs and welfare organizations to allow IEP students to volunteer for the local communities, which can serve dual purposes of improving English proficiency and developing an identity as a legimate member of the local communities.

In addition, findings of the present study suggest that the learners tend to be trapped in the dichotomy between native speakers and non-native speakers and quick to accept their subject identity as "non-native" speakers of English. Accepting the identity as a non-native speaker may lower the learner's confidence in speaking English because it implies that the learner is not a legitimate and proper speaker of the language. Intensive English programs can help learners break away from this dichotomy by showing them that language is just a set of symbolic tools used to mediate relationships between people. When students realize this, they can gradually shift away from the perspective of treating English as a subject matter they need to master to become native speakers. Instead, they can start to adopt a new perspective of treating English as a tool kit that they learn to approximate to assume certain identities in the target speech community. In this sense, a holistic IEP curriculum from SCT perspective focuses on teaching students how to use linguistic resources appropriately for certain roles and identities in various authentic situations rather than offering students separate courses for reading, writing, grammar, speaking, and listening. 


\section{Conclusion}

In the present study, three cases of IEP students from Korea were examined with respect to their motivations, imagined communities, and subsequent struggles in language learning. The highly motivated participants were excited about being immersed in American society and culture and improving English language competence. Their imaginations of target language communities were influenced by stories from friends and family, widespread beliefs about study abroad, and descriptions of America in the media. The in-depth interviews revealed that these learners experienced struggles in finding opportunities for authentic interactions with local people and struggles in making bids for identites as legimate membersof the communities of practice. After repeated attempts and failures to gain access to the local communities, the three participants took different strategies to cope with the reality.

There are limitations to the present study. Firstly, it was a small-scale study with three participants. While a detailed description of experiences on a certain phenomenon provides valuable insights from the participants' perspectives, a large-scale study with both qualitative and quantitiative data sets may produce findings that are more generalizable to a larger learner population. Secondly, the present study did not explore possible causal relationships between motivations, imaginations, and language learning outcomes. It would be interesting to investigate if there are any significant correlations among different factors that were discussed in the present study. Finally, the present study was exploratory in nature, but its findings can be useful in conducting action research to design a more effective IEP that assists learners to gain membership to local communities of practice and evaluate the program effectiveness.

\section{Acknowledgements}

The research was supported by a 2014 Hankuk University of Foreign Studies research grant.

\section{References}

Allen, H. W. (2010). Language-learning motivation during short-term study abroad: An activity theory perspective. Foreign Language Annals, 43(1), 27-49. http://dx.doi.org/10.1177/1028315309334739

American Association of Intensive English Programs. (2014). About EnglishUSA. Retrieved August 10, 2014, from http://www.englishusa.org/about-english-usa

Creswell, J. W. (1998). Qualitative inquiry and research design: Choosing among five traditions. Thousand Oaks, CA: Sage.

Hawkins, M. R. (2004). Researching English language and literary development in schools. Educational Researcher, 33(3), 14-25. http://dx.doi.org/10.3102/0013189X033003014

Kim, J. (2013). Korean ESL graduate students' investments, social identities, and imagined communities (Unpublished M.E. Thesis). University of Washington.

Kim, T. (2008). Korean immigrants' English learning motivation and learner beliefs in Toronto: A qualitative case study based on Nvivo. The Sociolinguistic Journal of Korea, 16(2), 141-168.

Kim, T., \& Yang, J. (2010). Learner beliefs in study-abroad experience: A qualitative case study of two Korean ESL learners. English Teaching, 65(2), 75-100.

Freed, B. F. (1995). What makes us think that students who study abroad become fluent? In B. F. Freed (Ed.), Second language acquisition in a study abroad context (pp. 123-148). Philadelphia, PA: John Benjamins Publishing Company. http://dx.doi.org/10.1075/sibil.9.09fre

Johnson, M. (2004). A Philosophy of second language acquisition. London: Yale University Press.

Kanno, Y., \& Norton, B. (2003). Imagined communities and educational possibilities: Introduction. Journal of Language, Identity, and Education, 2(4), 241-249. http://dx.doi.org/10.1207/S15327701JLIE0204_1

Kinginger, C. (2004). Alice doesn't live here anymore: Foreign language learning and identity reconstruction. In A. Pavlenko, \& A. Blackledge (Eds.), Negotiation of identities in multilingual contexts (pp. 219-242). Clevendon, U.K.: Multilingual Matters Ltd.

Lantolf, J. P. (2000). Introducing sociocultural theory. In J. P. Lantolf (Ed.), Sociocultural theory and second language learning (pp. 1-26). Oxford: Oxford University Press.

Norton, B. (2000). Identity and language learning Social processes and educational practice. Essex, UK: Pearson Education.

Pavlenko, A., \& Lantolf, M. R. (2000). Second language learning as participation and the (re)construction of 
selves. In J. P. Lantolf (Ed.), Sociocultural theory and second language learning (pp. 155-177). Oxford: Oxford University Press.

Pierce, B. N. (1995). Social identity, investment, and language learning. TESOL Quarterly, 29(1), 9-31. http://dx.doi.org/10.2307/3587803

Schecter, S., \& Bayley, R. (1997). Language socialization practices and cultural identity: Case studies of Mexican descent families in California and Texas. TESOL Quarterly, 31, 513-542. http://dx.doi.org/10.2307/3587836

Sfard, A. (1998). On two metaphors for learning and the dangers of choosing just one. Educational Researcher, 27(2), 4-13. http://dx.doi.org/10.3102/0013189X027002004

Strauss, A., \& Corbin, J. (1998). Basics of qualitative research: Techniques and procedures for developing grounded threory (2nd ed.). Thousand Oaks, CA: Sage.

Swain, M., \& Lapkin, S. (1998). Interaction and second language learning: Two adolescent French immersion students working together. The Modern Language Journal, 82, 320-337. http://dx.doi.org/10.1111/j.1540-4781.1998.tb01209.x

Talburt, S., \& Stewart, M. A. (1999). What's the subject of study abroad? Race, gender and "living culture". The Modern Language Journal, 83, 163-175. http://dx.doi.org/10.1111/0026-7902.00013

Watkins-Goffman, L. (2001). Lives in two languages: An exploration of identity and culture. Ann Arbor: The University of Michigan Press.

Weger, H. (2013). Examining English language learning motivation of adult international learners studying abroad in the U.S. RELC Journal, 44(1), 87-101. http://dx.doi.org/10.1177/0033688212473272

Wilkinson, S. (1998). On the nature of immersion during study abroad: Some participant perspectives. Frontiers: The Interdisciplinary Journal of Study Abroad, 4, 121-138.

\section{Copyrights}

Copyright for this article is retained by the author(s), with first publication rights granted to the journal.

This is an open-access article distributed under the terms and conditions of the Creative Commons Attribution license (http://creativecommons.org/licenses/by/3.0/). 